\title{
Political Change, Women's Rights, and Public Opinion on Gender Equality in Myanmar*
}

\author{
Mala Htun ${ }^{\dagger} \&$ Francesca R. Jensenius ${ }^{\ddagger}$
}

This is a pre-copyedited version of an article appearing in The European Journal of Development Research (doi.org/10.1057/s41287-020-00266-z), published online March 2020.

\begin{abstract}
Myanmar's introduction of competitive elections after decades of military rule raised expectations for progress in economic and social development, including in the area of women's rights. In this paper, we draw on data from two national surveys, fieldwork, and existing qualitative studies to explore public opinion on women's rights and gender equality. Do Burmese people support gender equality? How are their views on gender related to other aspects of political culture, such as traditional values and views toward authoritarianism and democracy? Our objective is to gain better understanding of the opportunities and obstacles to egalitarian social change and democratic consolidation. Our analysis of survey data reveals that attitudes toward gender roles are conservative, traditional and anti-democratic beliefs are widespread, and these views are strongly associated. Our findings imply that tendencies in public opinion provide a resource for Burmese nationalist groups and politicians and an obstacle to activists seeking greater alignment with global norms on gender equality.
\end{abstract}

Keywords: Myanmar, women's rights, public opinion, political culture, gender equality, nationalism

${ }^{*}$ The research was conducted with support from the Andrew Carnegie Corporation and the Norwegian Research Council (project number 250753). We are grateful to Ryan Roco for sharing data with us from his fieldwork in Myanmar. We thank Kim Ninh of the Asia Foundation for making their survey data available to us and we appreciate the Asian Barometer's release of their 4th wave survey data on Myanmar. The paper benefitted from comments by Elin Bjarnegard and participants in the workshop on Development Challenges in Myanmar at Uppsala University. The authors confirm that there is no conflict of interest.

${ }^{\dagger}$ Professor of Political Science, University of New Mexico. E-mail: malahtun@unm.edu.

${ }^{\ddagger}$ Professor of Political Science, University of Oslo, and Senior Research Fellow, Norwegian Institute of International Affairs. E-mail: f.r.jensenius@stv.uio.no. 


\section{Introduction}

Myanmar's experience has rarely informed comparative analysis of gender politics. The country has historically been closed to much of the world and successive authoritarian governments did not allow most scholars to gather systematic data on social conditions and public opinion. Political liberalization in the 2010s has, for the first time in decades, enabled a greater number of local and foreign scholars and organizations to conduct in-country research. As a result, we can begin to use contemporary social science methods to explore questions about the prospects for gender-equal social change.

In this paper, we draw on data from two national surveys, fieldwork, and existing qualitative studies to explore public opinion on women's rights and gender equality in Myanmar. Women's status has historically been low and Burmese people have tended to endorse male dominance in the family, politics, economy, and society, particularly in the numericallydominant Buddhist community (Crouch 2016; Harriden 2012; Khaing 1984; Minoletti 2019; Than 2013). The movement toward competitive elections increased the hopes of activists and scholars in Myanmar and across the world for progress in economic and social development after decades of repressive authoritarian rule. The fact that the country's de facto leader is Aung San Suu Kyi, a world-famous woman and winner of the Nobel peace prize, has heightened expectations about advances in women's rights.

Do Burmese people support gender equality? How are their views on gender related to other aspects of political culture, such as traditional values and views toward authoritarianism and democracy? Probing public attitudes toward gender, as well as tendencies in political culture more generally, is important to identify the opportunities and obstacles to egalitarian social change and the consolidation of democracy. Until relatively recently, however, we have not had enough systematic data on public attitudes to conduct a holistic assessment. We analyze whether conservative views on gender persist in the 2010s, whether 
these views are linked to traditional and authoritarian attitudes, and we speculate about the implications for gender equality and democracy.

In this paper, we show that the Burmese public holds conservative views, both in general and toward women and gender. We draw on national surveys from the Asia Foundation and the Asian Barometer, which reveal that most people across all age groups believe that men are more capable leaders than women in business and politics, consider it more important for boys than girls to receive a university education, and favor boy children. These findings conform to the results of ethnographic and historical studies of Myanmar (Crouch 2016; Harriden 2012; Khaing 1984; Than 2013), qualitative research conducted in the country in the 2010s (Barrow 2015; Gender Equality Network 2015a,b; Minoletti 2014; Oxfam 2013), and interviews and observations by our own field research team. Our specific contributions are twofold: we affirm other scholars' observations of conservative attitudes on women and gender with nationwide survey data, and we show that views on gender are strongly associated with traditional values and anti-democratic beliefs but not with the frequency of religious practice.

Though the greater political freedom of the 2010s has enabled some progress on gender equality in Myanmar, we have also seen the erosion of liberal rights in some areas. Restrictive legislation on women's rights - intended to protect the Burman "race" and the Buddhist religion - enjoys broad societal support (David and Holliday 2018; Foundation 2014; Gender Equality Network 2015b; Minoletti 2016; Welsh and Huang 2016). Our findings suggest that the prominence of traditional and authoritarian values among voters constitutes a key obstacle for advocates of women's rights and a resource to nationalist politicians and activists, who can gain prominence by tapping into a reservoir of conservative sentiments. Contemporary tendencies in public opinion have helped to fuel the resurgence of nationalist, illiberal, and exclusionary movements, which have a long history in Myanmar (Crouch 2015; Than 2015; Walton and Hayward 2014). Our analysis is consistent with other studies, including David and Holliday (2018) and Stokke and Soe Myint Aung in this volume, which show that there 
has been more change in the appearance of Myanmar's political regime than in underlying practices, norms, and attitudes.

\section{Political change and gender equality}

For decades, the basic tenets of modernization theory held sway in the social sciences. Modernization theorists believe that economic growth, cultural changes, and transitions to democratic governance tend to go together and are interrelated in a coherent way. Socioeconomic modernization helps create conditions for democracy and changes in values toward self-expression, secularization, and support for gender equality (Inglehart and Norris 2003; Inglehart and Welzel 2005; Norris and Inglehart 2011). As Inglehart and Welzel put it, "modernization brings cultural changes that make democracy the logical institutional outcome" (Inglehart and Welzel 2005). Political transitions, such as the one occurring in Myanmar, thus come with great expectations of cultural changes toward equality.

Religion is a crucial dimension of the hypothesized connection between cultural change and gender equality. Across many societies, secularization-which involves a decline in religious beliefs and participation - is associated with greater support for equality between men and women (Inglehart and Norris 2003). In contexts where religious beliefs are strong, by contrast, there tends to be less support for gender equality (Ibid). Another important aspect of secularization is the separation of the state from religious organizations. When the state is not secular, it often supports, favors, and regulates ecclesiastical institutions, while justifying its existence and decisions with religious principles (Creppell 2010). Under such conditions - which hold in Myanmar (Crouch 2015) - religious pluralism tends to decline, religious organizations grow more top-heavy, and religious doctrine becomes more resistant to internal deliberations and feminist interpretations. As a result, close religion-state relations 
tend to be associated with more discriminatory laws on women and gender (Htun and Weldon 2018).

Empirically, the effects of political and economic development on cultural change toward gender equality have been mixed. In most of the West and Latin America, people tend to support equal education for men and women, the idea of women serving as political leaders, and women's right to work. The evolution of these views on gender tends to be associated with the decline in traditional values and religiosity as well as with growing support for free expression (Inglehart and Norris 2003; Inglehart and Welzel 2005).

Yet elsewhere, views on gender roles remain traditional and help to account for major political outcomes, such as the weakness of democracy (Fish 2002, 2011). In East and Southeast Asia in particular, gender-related attitudes remain conservative relative to the West. There is often a discrepancy between women's political status and their social status, which explains why women's political presence can be relatively high in some countries in the region at the same time that women's overall political engagement remains low. Due to the context of gender inequality, women do not see female leaders as role models and the presence of women in power does not inspire other women to participate in politics (Liu 2018).

What is more, Asian countries have experienced dramatic socioeconomic changes and achieved high levels of development without embracing the cluster of liberal values that underlie the success of democratic regimes elsewhere in the world. These values include support for horizontal accountability and other checks on executive power, political and social pluralism, civic association, and equal participation. Surveys show that popular majorities across 11 East and Southeast Asian countries, including rich countries, prefer non-democratic and hybrid forms of political regime, while only a small minority endorse liberal values (Chu et al. 2008; Shin and Kim 2017; Welsh et al. 2016). 
Especially in contexts with conservative political cultures that tend to be less supportive of gender equality, the introduction of more competitive politics may be associated with backsliding on women's rights. Across multiple countries, freer politics have created opportunities for traditional and nationalist forces to mobilize and gain support. In Roman Catholic countries such as Brazil, Chile, and Poland, conservative groups and legislators opposed government initiatives on gender equality and produced legislative rollbacks (Araújo et al. 2018; Baldez 2001; Corrêa 2017; Grzymała-Busse 2015; Haas 2011; Heinen and Portet 2010; Rosado-Nunes 2015). In Muslim-majority Niger, conservative activists repeatedly blocked feminist and secular attempts to expand women's rights and remove discriminatory provisions in family law. Invoking Islamic values and branding reformists as "Satanic," conservatives framed the liberalization of family law as an attack on the nation (Kang 2015). Religious and nationalist actors opposed to women's rights may be particularly influential in new democracies where the state is weak and governments seek legitimacy by cultivating ecclesiastical support.

In summary, though the lingering influence of modernization theory suggest that liberalizing movements in politics, the economy, and society reinforce each other, in reality, progressive social trends sometimes work at cross purposes. Conflict over women's rights in democratizing and democratic polities affirms Przeworski's concept of democracy as "institutionalized uncertainty": democratic procedures ensure fair play, he argues, while not guaranteeing a particular set of outcomes (Przeworski 1991). Freer elections do not always go with liberal democracy, where citizens enjoy constitutional guarantees of equal individual rights. On the contrary: many chief executives around the world have used the power they achieved through elections to roll back civil and political rights (Levitsky and Ziblatt 2018; Zakaria 1997). Nor do competitive elections always help the cause of liberal feminism, which requires that the state and major social actors endorse the notion that women and men should have equal opportunities, rights, and obligations. Instead, elections can lead to 
greater contestation about the meaning and significance of gender and of women's roles in society (Htun 2003; Kang 2015; Razavi and Jenichen 2010).

As we show below, Myanmar experienced competing trends in the 2010s. Feminist movements enjoyed some success in changing government discourse and extracting official commitments, but conservative nationalist groups also achieved legislative victories. Through an exploration of public opinion on gender, traditionalism, and authoritarianism, we suggest that the stalled progress on women's rights may be partially attributable to tendencies in political culture. Our analysis of survey data reveals widespread adherence to conservative views across all age groups. Conservative public opinion presents a challenge to feminist movements seeking to align domestic laws and practices with international norms on gender equality and a resource for nationalist groups opposed to equal rights.

\section{Methods and data}

One of the main hurdles to studying women's rights in Myanmar, and particularly attitudes about gender equality, has been the dearth of accessible public opinion data. As a result of political liberalization over the past 10 years, a growing number of organizations have been able to conduct national surveys on a range of topics. In this paper we analyze two of the first nationally-representative surveys relevant to political research in the country: the Asia Foundation's 2014 survey of "Civic Knowledge and Values in a Changing Society" and the first round of the Asia Barometer Survey (ABS) conducted in 2015. The former includes a set of questions about gender roles, giving us a sense of overall tendencies in public opinion related to gender equality. The latter contains a couple of questions on gender in addition to scales measuring different dimensions of conservatism-traditionalism and authoritarianism - as well as indicators of religiosity, which allows us to look at how these attitudes relate to opinions about gender roles in the Myanmar context. ${ }^{1}$ 
Collecting and analyzing survey data in a country like Myanmar is difficult. The technical reports produced by the Asia Foundation and ABS survey teams identify some of these challenges. The teams spent time familiarizing personnel and respondents with survey methodology since surveys were new to both (Welsh and Huang 2016, p. x). They developed the survey instruments, translated them, and fielded surveys in multiple languages to reach different groups of Myanmar's multi-ethnic population (Foundation 2014, p. 23). Interviewers reported of high level of cooperation from the respondents, but also concerns that respondents failed to understand some questions, which they attributed to the fact that surveys are still uncommon in Myanmar (Welsh and Huang 2016, p. 6). Researchers also had to figure out how to sample respondents in a context where reliable census data was not available (Foundation 2014, p. 113).

Although the survey teams sought to make the language in the surveys as accessible as possible, the share of "don't know" responses was high in both the Asia Foundation survey (Foundation 2014, p. 23) and the ABS (Welsh and Huang 2016, p. 6). This was also true for the IRI survey conducted around the same time. ${ }^{2}$ The high share of "don't know" responses is likely due to respondents' lack of familiarity with political discussions since they had lived in authoritarian setting for a long time and that they were not used to surveys. To alleviate concerns that the high share of "don't know" responses biases our estimates, we report the share of "don't knows" in addition to the different responses in the surveys. We also include the "don't know" responses in the denominator when calculating the share of affirmative responses to questions.

Since we analyze survey data produced by other researchers in the past, we cannot make changes to the survey design. Both surveys contain another limitation relevant to our purposes. It is standard social scientific practice to measure complex constructs such as support for gender equality with validated, multi-item scales and not with a small number of questions (see, e.g., Glick and Fiske 1996; Inglehart and Norris 2003). Though the ABS 
uses validated scales for traditionalism and authoritarianism, it does not include a scale of gender beliefs, nor does the Asia Foundation study.

Notwithstanding the lack of a gender belief scale, the presence of similar patterns across the two independently-conducted surveys that we look at increases our confidence in the data. In addition, the survey data conforms to findings of in-country qualitative research, including interviews and focus groups throughout the country (Gender Equality Network 2015a,b; Minoletti 2014).

We complement the analyses of the survey data with insights from qualitative data and documents gathered during field research trips to Myanmar in 2016 as well as observations and conversations during several other trips to the country. The fieldwork was conducted by [names withheld to keep paper anonymous]. They were based in [location withheld], but traveled to Myanmar where they reached out to both expert and ordinary men and women to learn about their attitudes and behavior regarding gender roles, violence against women, women's work experiences, and other related issues. The team conducted a total of 29 semi-structured interviews in English or Burmese, depending on interviewee preference.

\section{Views on gender in the Asia Foundation Survey}

The first survey we look at is "Myanmar 2014: Civic Knowledge and Values in a Changing Society," a nationwide study carried out by The Asia Foundation in 2014 to "document public knowledge and awareness of new government institutions and processes, and to gauge the political, social, and economic values held by people of diverse ethnic and religious backgrounds" (Foundation 2014, p. 11). Some 3,000 respondents from all the states and regions of Myanmar were interviewed - 900 from the regions and 300 from each of the seven states (Foundation 2014, p. 22). ${ }^{3}$ 
We were interested in this survey because it has four questions directly related to views on gender roles, as well as regional indicators allowing us to look for geographic variation in attitudes. First, it asks respondents whether they believe men make better political leaders than women. Here, $70 \%$ of the respondents $(72 \%$ of men and $68 \%$ of women) answer that they agree strongly or somewhat with this statement. Some $7 \%$ of men and $11 \%$ of women say they don't know or refuse to answer. The rest say they disagree. There are considerable differences by region, as can be seen in Figure 1. The highest affirmative response - $79 \%$-is in Ayeyarwady region and the lowest - 60\% — is in Bago region.

Figure 1: Percentage agreeing that men make better political leaders than women (left panel) and that a university education is more important for a boy than a girl (right panel)

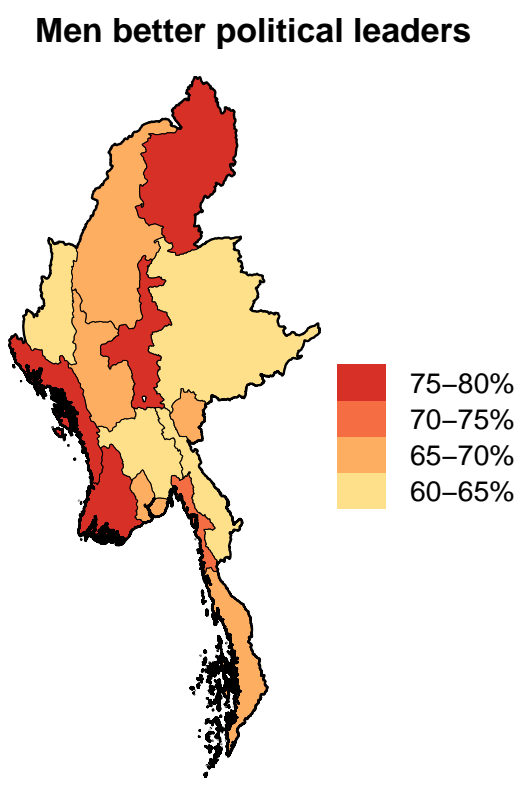

University for boys

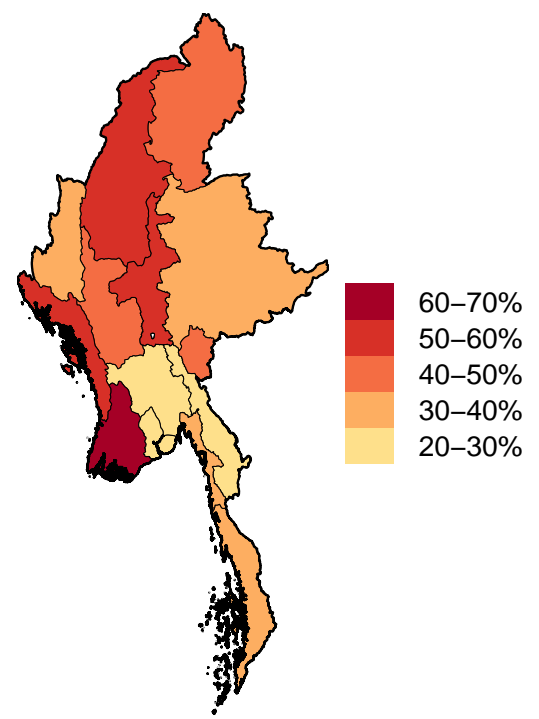

We see a similar regional pattern for the second direct question about gender: the respondents are asked whether a university education is more important for a boy than for a girl. Here, $39 \%$ (41\% of men and $38 \%$ of women) say they agree, $5 \%$ of men and $7 \%$ of women say they don't know, and the rest disagree. For this question too, Ayeyarwady has the highest affirmative rates with $63 \%$ agreeing. Bago has among the lowest, with $24 \%$ agreeing. (Kayin 
had the lowest value with $20 \%$ agreeing.) These regional patterns are shown in the right panel of Figure 1.

Respondents were then asked whether men make better business leaders than women. To this, $70 \%$ say they agree ( $72 \%$ of men and $70 \%$ of women); $4 \%$ of men and $7 \%$ of women say they don't know; the rest disagree. Ayeyarwady is again one of the regions with the highest affirmative rate with $79 \%$ agreeing (the highest is Rakhine state with $83 \%$ ). Bago region, with $63 \%$ agreeing, is again among the lowest, though here the lowest is Yangon with 57.5\% agreeing.

Finally, the survey asks whether women should make up their own minds when they vote. Some $80 \%$ of the respondents ( $79 \%$ of men and $81 \%$ of women) answer affirmatively, $2 \%$ of men and $4 \%$ of women say they don't know, and the rest disagree. Here too, Bago region stands out with $91 \%$ of the respondents agreeing that women should make up their own mind. Tanintharyi has the lowest score, with only $66 \%$ agreeing, and the Mandalay region is a close runner-up with $68 \%$ agreeing.

Crucially, there is almost no association between age and responses to the four questions about gender roles, as we show in in Figure 2. The figure shows that there is virtually no relation between age and seeing men as better political leaders, better business leaders, or agreeing that women should make up their own mind when they vote. We see a weak agerelated trend only for the question about university being more important for boys than for girls, as older people are somewhat more likely to agree.

In Table 1 we show the association between responses to the four questions on gender and age in a multivariate setting, controlling for other characteristics of the respondents. ${ }^{4}$ Consistent with the pattern shown in Figure 2, the analysis presented in the table shows a positive association between age and the question about university being more important for boys, though this relationship is not statistically significant. On the other hand, the association between age and responses to the question about men being better business 
Figure 2: Age of respondents and gender attitudes in the Asia Foundation Survey
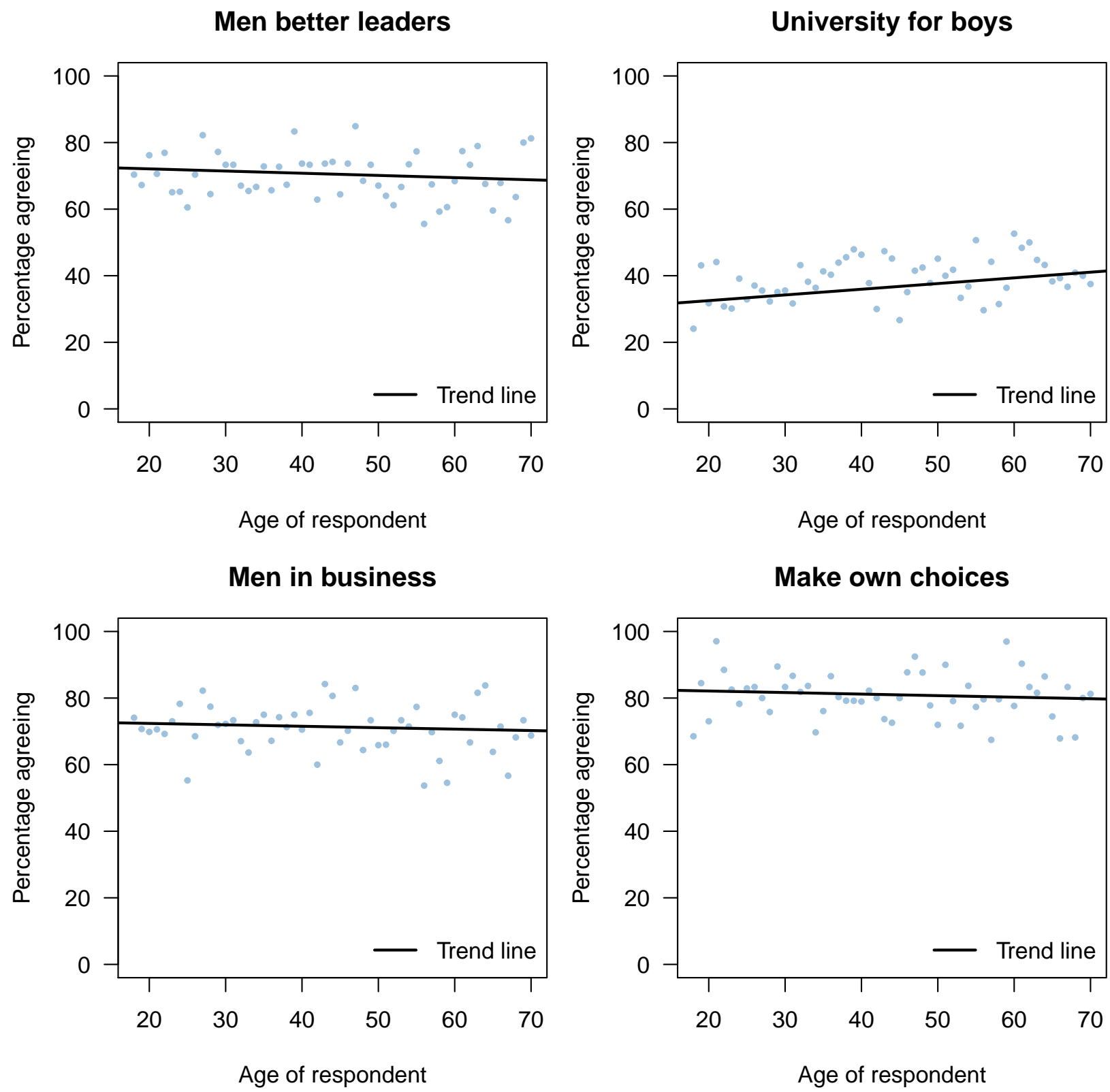

leaders is negative and statistically significant: older people are somewhat less likely to say that men make better business leaders than women.

Our analysis of Asia Foundation survey data shows that gender unequal attitudes are consistent across age groups, which suggests that public opinion about gender equality in 
Myanmar is unlikely to occur simply due to the passage of time, as a younger generation replaces an older one. Political cultural obstacles to advancements in women's rights are strong.

Table 1: Ordinary Least Square Regression Models of Gender Attitudes on Age

\begin{tabular}{lcccr}
\hline & $\begin{array}{c}\text { Men better } \\
\text { leaders }(\%)\end{array}$ & $\begin{array}{r}\text { University } \\
\text { for boys }(\%)\end{array}$ & $\begin{array}{r}\text { Men in } \\
\text { business }(\%)\end{array}$ & $\begin{array}{r}\text { Make own } \\
\text { choices }(\%)\end{array}$ \\
\hline Age & -0.02 & 0.09 & $-0.13^{*}$ & 0.05 \\
Urban locality & $(0.07)$ & $(0.07)$ & $(0.06)$ & $(0.06)$ \\
Woman & -2.29 & -2.35 & 0.71 & $2.89^{\dagger}$ \\
& $(2.13)$ & $(2.20)$ & $(2.09)$ & $(1.74)$ \\
Married & -2.64 & -0.88 & $-3.76^{*}$ & $3.75^{*}$ \\
& $(1.80)$ & $(1.88)$ & $(1.81)$ & $(1.55)$ \\
Working & 2.29 & $6.72^{* * *}$ & $6.52^{* * *}$ & -2.41 \\
& $(1.95)$ & $(1.94)$ & $(1.95)$ & $(1.59)$ \\
Education level & -0.53 & 0.52 & $-6.88^{* * *}$ & -0.77 \\
& $(2.11)$ & $(2.15)$ & $(2.03)$ & $(1.73)$ \\
Income level & $1.42^{*}$ & $-2.19^{* * *}$ & $-1.28^{*}$ & $2.84^{* * *}$ \\
& $(0.58)$ & $(0.58)$ & $(0.58)$ & $(0.45)$ \\
& -0.35 & $-1.17^{*}$ & $-1.37^{* *}$ & 0.28 \\
State/regional FEs & $(0.45)$ & $(0.46)$ & $(0.45)$ & $(0.35)$ \\
$N$ & Yes & Yes & Yes & Yes \\
adj. $R^{2}$ & 2916 & 2916 & 2916 & 2916 \\
\hline
\end{tabular}

Heteroscedasticity-consistent standard errors in parentheses.

$\dagger$ significant at $p<.10 ;{ }^{*} p<.05 ;{ }^{* *} p<.01 ;{ }^{* * *} p<.001$

\section{Gender attitudes and political culture in the Asian Barometer Survey}

The second survey we look at is the Asian Barometer (ABS) for Myanmar, conducted from January to March 2015 (Welsh and Huang 2016, p. 2). This study is part of the fourth wave of the Asian Barometer, but is the first one in Myanmar. The study covers all 15 of Myanmar's administrative regions, including the capital Nay Pyi Taw. It is nationally 
representative of the adult population, with 1,620 respondents selected through random stratified sampling from available population data (Welsh and Huang 2016, p. 5). All respondents were interviewed face-to-face. Among the 1,620 respondents there were 811 women. The respondents ranged in age from 18 to 64 , with an average age of 42 . About $80 \%$ were (or had been) married.

\subsection{Attitudes on gender roles}

Two questions in the survey ask respondents directly about their gender-related attitudes. Respondents are asked how they feel about the statement "Women should not be involved in politics as much as men." This question is similar to the question about men as leaders that we examined in the Asia Foundation survey, but frames women in a negative way. Even with this stronger wording, $34 \%$ of men and $43 \%$ of women say they agree (strongly or somewhat) with this statement; $4 \%$ of men and $10 \%$ of women say that they don't know; the rest disagree. There is a large difference between NLD voters and others: only $24 \%$ of NLD voters agree with this statement, compared with $53 \%$ of the USDP voters and $40 \%$ of voters supporting other parties, possibly due to their support of Aung San Suu Kyi's leadership.

In response to the other gender question, $56 \%$ of respondents $-63 \%$ of the men and $50 \%$ of the women - say they strongly or somewhat agree with the statement "if one could have

only one child, it is more preferable to have a boy than a girl." Some $4 \%$ of the men and $7 \%$ of the women did not answer the question. The rest say they disagree.

Answers to the boy preference question reflect beliefs about the superiority of men, common across almost all classes and groups, which have been observed by multiple scholars working on Myanmar and by our own research team (see, e.g., Harriden 2012; Khaing 1984; Than 2013). For example, one of our interviewees, an educated woman from a prominent family who had lived abroad, stated that, "Even with my father or uncles, whatever the situation is, I always put them first. This kind of thinking and habits have become very 
ingrained [...] For example, the man will always sit in the front; like my husband and father I'll let them sit in front of me. And also when we eat, we $u$ cha them-let them have the food first at a meal table. It's been that way since I was really young, it's really hard to suddenly start changing." ${ }^{5}$ Reflecting on a day spent interviewing five women in Hlaing Thar Yar on the outskirts of Yangon, our team observed that: "Various male behaviours (such as verbal harassment, provocation, and threats) were discussed as acceptable (even if undesirable), natural, and inevitable. Relations between men and women that objectify women or aim to control or police women's behaviours are normalised and even legitimised according to Buddhist, Islamic, or Bamar (Burmese) ethnic values." ${ }^{6}$ Elsewhere in Asia, the boy preference is associated with (often severely) distorted sex ratios, the phenomenon of "missing women," and a surplus of men (Dreze and Sen 2002; Hesketh and Xing 2006; Sen 2001)

Burmese participants in a national study conducted by Gender Equality Network told the research team that women who give birth to boys have hpon, while women who give birth to girls have no hpon, and attributed the differential treatment of boy and girl children in the family to underlying boy preference (Gender Equality Network 2015b). Many Burmese believe that hpon, a concept referring to spiritual power or force, is possessed primarily by men and only in lesser form by women. Though many people today do not acknowledge the role of hpon explicitly, behaviors reflecting it live on in everyday social relations (Khaing 1984; Walton et al. 2015). For example, the need to preserve a man's hpon implies avoidance of polluting factors such as a woman's menstruation and childbirth (Gender Equality Network 2015b). ${ }^{7}$ In villages and even in some urban areas, people who wash clothes by hand still separate men and women's clothes, particularly clothing for the lower part of the body, hang women's longyis on a separate line to dry, usually in a more secluded area, and avoid using the same iron for men and women. Men tend to avoid walking under drying longyis. ${ }^{8}$ Hpon 
is a site of feminist resistance: one educated woman we interviewed remarked that she washes men and women's clothes together as a way to contest sexist traditions. ${ }^{9}$

The preference for boys is stronger in Myanmar than in other Southeast Asian countries. A comparison of countries where the survey is conducted in the region shows that some $60 \%$ if the respondents in Myanmar agree that they prefer a boy, compared to $46 \%$ in the Philippines (the second highest among the ABS countries), and 30\% in Cambodia (the lowest among the ABS countries) (Welsh and Huang 2016, p. 25). ${ }^{10}$

Similarly to what we see in the data in the Asia Foundation Survey, there is almost no association between gender attitudes and age, as shown in Figure 3. Younger respondents are not more or less likely to say that women have a role in politics or to express a preference for boy children.

Figure 3: Gender attitudes and age of respondents

Women should not be in politics

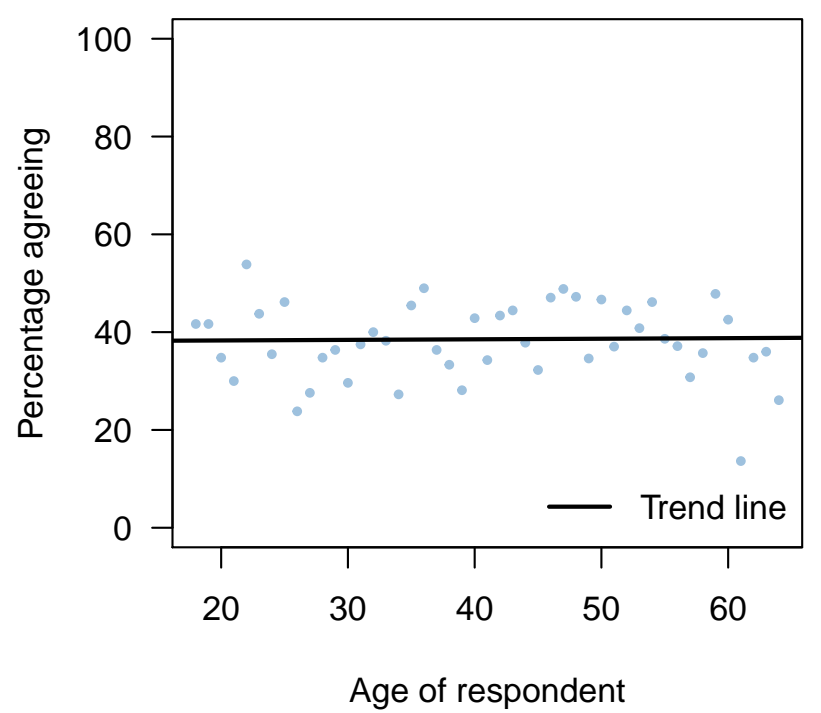

Preference for boy

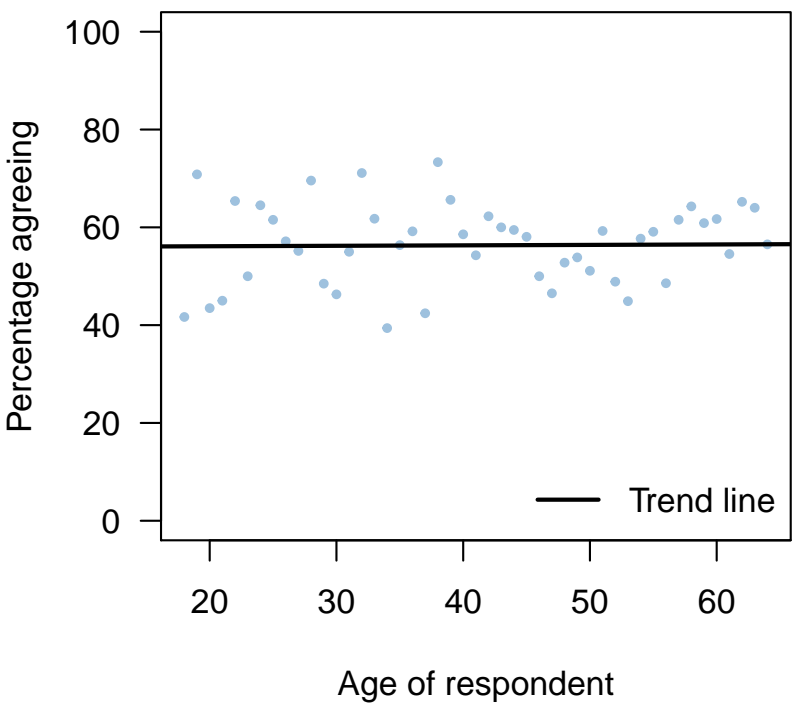




\subsubsection{Traditionalism, authoritarianism, and religiosity}

As we argued earlier in the paper, scholars influenced by modernization approaches contend that changes in beliefs about gender are related to other dimensions of political culture (Inglehart and Norris 2003; Inglehart and Welzel 2005). In this section, we assess the two dimensions of political culture emphasized in background papers informing design of the ABS - traditionalism-modernity and authoritarian-democratic values - in addition to a score on religiosity. How do traditional and authoritarian values relate to attitudes about women and women's rights in the Myanmar context?

The traditionalism concept comes from modernization theory. "Tradition" refers to a set of attitudes that characterize all societies "at a certain stage in their history prior to modernization." The concept of traditionalism in the ABS intends to measure "a pattern of attitudes in rural and low-class urban Asia during the course of several decades before the outbreak of World War II" (Nathan 2003, p.2,4).

The measurement used in the ABS survey assesses aspects of traditionalism that are relevant to Asia, such as familism, deference, conflict-avoidance, and an aversion to self assertion, based on scales developed by H.C. Kuan and S.K. Lau in Hong Kong, who were in turn influenced by Max Weber and Lucien Pye (Nathan 2003, 2007). The traditionalism scale includes 13 statements such as "For the sake of the family, the individual should put his personal interests second," "Being a student, one should not question the authority of their teacher," "Even if there is some disagreement with others, one should avoid the conflict," and "When dealing with others, one should not only focus on immediate interest but also plan for future." Respondents may "strongly agree", "somewhat agree", "somewhat disagree", or "strongly disagree" with each of these statements. ${ }^{11}$ The scale sums the "strongly agree" and "somewhat agree" responses and runs from 0 to 13, where 0 indicates weak adherence to traditional values and 13 indicates strong adherence to traditional values. 
In Myanmar, the average traditionalism score of the respondents to the survey is 11 , indicating that most can be considered highly traditional. ${ }^{12}$ Burmese participants in the ABS expressed the strongest adherence to traditional values in all of Southeast Asia (Welsh et al. 2016). The traditionalism score is similarly high among men and women, among those working and not working, and respondents of all age groups. It is somewhat higher among Buddhist respondents than those from other religious communities. It is also somewhat higher among both NLD supporters and USDP supporters than among those who do not sympathize with either party.

The ABS's assessment of authoritarian and democratic values asks questions about support for principles that support successful democracies such as equality, liberty, separation of powers, freedom to associate, and pluralism, while eschewing the word "democracy," which elicits almost unanimous support around the world and therefore offers little guide to variation in attitudes (Chu et al. 2008; Shin and Kim 2017). The measurement asks respondents whether they agree or disagree with a set of statements that includes "If the government is constantly checked (i.e. monitored and supervised) by the legislature, it cannot possibly accomplish great things," "Harmony of the community will be disrupted if people organize lots of groups, and "The government should decide whether certain ideas should be allowed to be discussed in society". ${ }^{13}$ Summing up how many of the statements the respondents agree with (strongly or somewhat) yields a scale running from 0 to 9 , where 0 indicates more democratic values and 9 indicates more authoritarian values. Here, the average value for Burmese respondents to the survey is 5.4, suggesting a weaker tendency towards authoritarian values than towards traditional ones. ${ }^{14}$ Still, Burmese overall register among the highest levels of authoritarian values in Southeast Asia, second only to Vietnam (Welsh et al. 2016).

Support for authoritarian values is on average somewhat higher among men than among women, among older rather than younger people, and among people who say they are not working. Furthermore, there are on average lower scores among people residing in large 
cities (those with a population of more than 100,000). Here too, authoritarian values are somewhat higher in the Buddhist community than in other communities. There is also a large difference by political party: USDP supporters are more likely to express authoritarian values (average of 6.3), compared to NLD supporters (average of 5.4) and those supporting other parties (average of 5.5).

We also look at the religiosity of the respondents, another important aspect of political culture which cross-national research shows is associated with traditionalism, authoritarianism, and support for conservative gender roles (Inglehart and Norris 2003; Inglehart and Welzel 2005). Welsh et. al.'s analysis of the ABS finds that the vast majority of Burmese reject the core liberal principle of the separation of the state from religion (Welsh et al. 2016). Indeed, there is a long tradition of ecclesiastical participation in Burmese politics and a high degree of government support for, regulation, and control of religion (Crouch 2015; Than 2015; Walton and Hayward 2014). Monks are widely seen as "champions of not only moral order but also political affairs" (Than 2015, p.16), and extreme actions are justified if their goal is to defend a religious community (Than 2015; Walton and Hayward 2014). Across multiple societies, strong connections between ecclesiastical powers and state institutions are associated with discriminatory laws and policies on women's rights (Htun and Weldon 2018). As this suggests, there are good reasons to expect religiosity to relate to gender inequality.

We coded respondents according to whether they say they practice religious services or rituals on a daily, weekly, or monthly basis, or less frequently. Table 2 shows the distribution of the responses. Some $72 \%$ of the respondents say they practice religion once a day or several times a day. Another $16 \%$ say they do so once a week or several times a week. Only $11 \%$ say they practice religion less than weekly. This corresponds well to the self-reported level of religiosity, where $47 \%$ self-report as "Very religious", $49 \%$ say they are "Moderately religious" and only about 4\% claim to be only "Lightly religious" or not religious at all. 
Table 2: Religious practice among respondents in the Myanmar Asian Barometer survey

\begin{tabular}{lrr}
\hline & Number & Percentage \\
\hline Daily & 1171 & 72 \\
Weekly & 257 & 16 \\
Monthly & 105 & 6 \\
Less than monthly & 87 & 5 \\
\hline
\end{tabular}

Our surprising finding is that people who practice religion frequently are not more likely to express traditional views and they are somewhat less likely to express authoritarian values. However, religiosity does seem to be related to participation in democratic politics. Devout respondents are more likely to say that they voted in the 2010 election: $72 \%$ of the people who practice religion daily say they voted, compared to $70 \%$ who practice weekly, $67 \%$ who practice monthly, and $63 \%$ who practice religion less than once a month. In addition, as we show below, religiosity is not associated with conservative views on gender in a multi-variate analysis.

\subsection{The association between traditionalism, authoritarianism, re- ligiosity, and gender inequality}

We conducted multiple analyses to probe the connections between traditionalism, authoritarianism, religiosity, and views on gender. There is a strong association between agreeing with the statement that women should not be involved in politics and expressing traditional and authoritarian values, as Figure 4 shows. On the other hand, there is little association between views on women and politics and religious practice.

In Figure 4, each of the small black dots represents the percentage of respondents agreeing with the statement that women should not participate in politics as much as men. The size of the gray bubble surrounding each dot indicates how many respondents are included in the calculation of the percentage. In the left panel, for example, the almost non-existent gray bubbles at the values 1 and 2 on the $\mathrm{x}$-axis indicate that almost no respondents (only 
1 and 2, respectively) have such a low score on the traditionalism scale. The corresponding percentage is 0 , as none of these non-traditional respondents agree with the statement about women not participating in politics. In comparison, 217 respondents have a traditionalism score of 10 and 534 respondents have a traditionalism score of 13, and a large share of these respondents agree that women should not participate in politics as much as men. The percentage agreeing remains below $40 \%$ up to a traditionalism score of 11 (the average score). However, among people with a traditionalism score of 12 , the percentage agreeing that women should not be much involved in politics rises to $42 \%$, and among those with a traditionalism score of 13 it rises to $52 \%$.

Figure 4: Respondents agreeing that women should not participate in politics as much as men
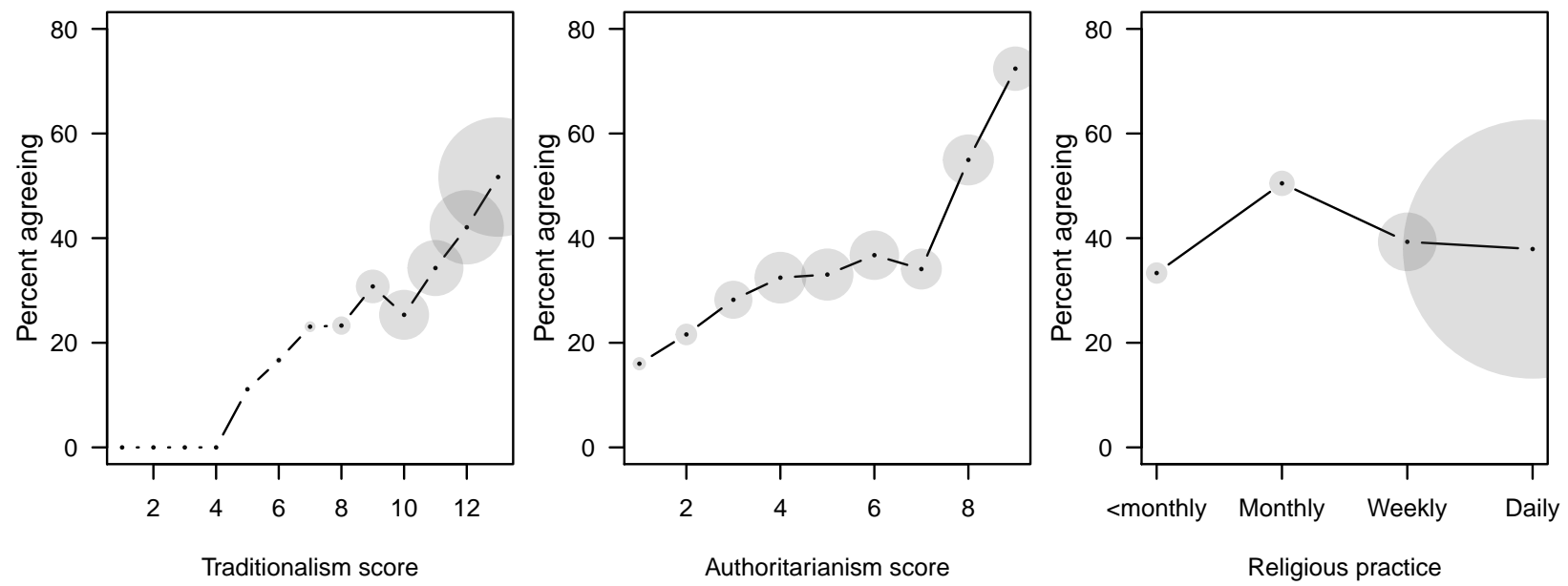

In the middle panel of Figure 4 we see the association between the authoritarianism score and the attitudes towards women and politics. From the size of the gray bubbles, we can see that the values on the authoritarianism scale are more spread out than on the traditionalism one. Here, the lowest average score $(16 \%)$ on the women in politics question is presented by people with an authoritarianism score of 1 . We see a slow increase in the percentage agreeing with the statement up to an authoritarianism score of 7 . After that we see a sharp increase 
with $55 \%$ agreeing among people with an authoritarianism score of 8 , and $72 \%$ agreeing among those with an authoritarianism score of 9 .

The right-most panel shows the association between beliefs about women's political participation and religiosity, measured with how often people say they practice their religion. Here, there is no clear pattern: more religious people do not express more conservative views.

A similar set of associations holds for answers to the question about boy preference. In Figure 5 we show the association between the traditional values score (on the left), the authoritarian values score (in the middle), and religiosity (on the right) and responses to the question about preferring a boy child. Whereas traditional and authoritarian values are correlated with boy preference, religious practice is not.

Figure 5: Respondents agreeing to the statement that a boy child is preferable
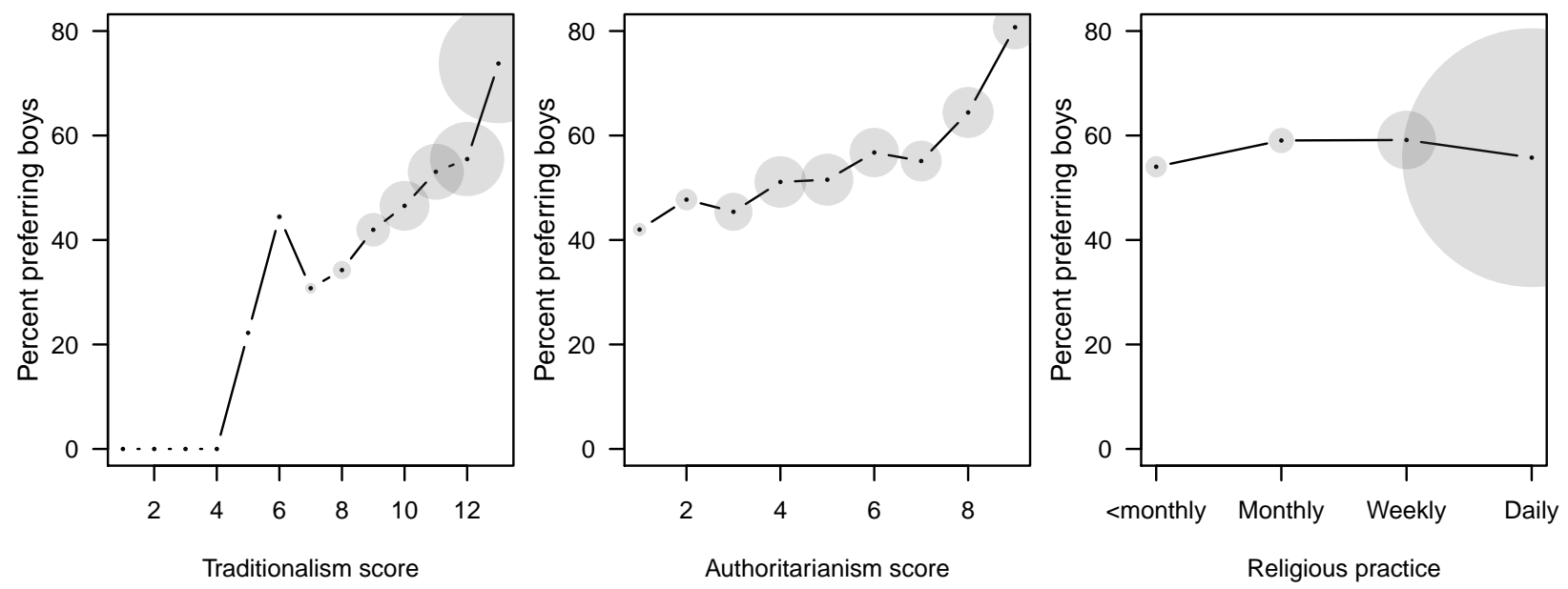

In Table 3 and Table 4 we show the robustness of the relationships between traditional, conservative, and religious values and anti-gender equality views in a multi-variate setting. In Table 3 we show the association with a preference for men in politics. Consistent with the descriptive patterns reported above, there is a large and significant association between both the traditionalism score (Model 1) and authoritarianism score (Model 2) and the propensity to say that women do not have a role in politics. Also consistent is the lack of a significant relationship between religious practice and gender-unequal views (Model 3). 
Table 3: OLS regression models of the association between conservative values and preference for men in politics

\begin{tabular}{|c|c|c|c|c|}
\hline & Model 1 & Model 2 & Model 3 I & Model 4 \\
\hline \multirow[t]{2}{*}{ Intercept } & $-0.23^{* * *}$ & $0.06^{\dagger}$ & $0.37^{* * *}$ & -0.02 \\
\hline & $(0.06)$ & $(0.03)$ & $(0.02)$ & $(0.11)$ \\
\hline \multirow[t]{2}{*}{ Traditionalism score } & $0.06^{* * *}$ & & & $0.02^{* * *}$ \\
\hline & $(0.01)$ & & & $(0.01)$ \\
\hline \multirow[t]{2}{*}{ Authoritarianism score } & & $0.06^{* * *}$ & & $0.05^{* * *}$ \\
\hline & & $(0.01)$ & & $(0.01)$ \\
\hline \multirow[t]{2}{*}{ Religious practice } & & & 0.01 & 0.01 \\
\hline & & & $(0.01)$ & $(0.01)$ \\
\hline \multirow[t]{2}{*}{ Age } & & & & 0.00 \\
\hline & & & & $(0.00)$ \\
\hline \multirow[t]{2}{*}{ Urban locality } & & & & -0.04 \\
\hline & & & & $(0.03)$ \\
\hline \multirow[t]{2}{*}{ Woman } & & & & $0.09^{* * *}$ \\
\hline & & & & $(0.03)$ \\
\hline \multirow[t]{2}{*}{ Married } & & & & $-0.07^{*}$ \\
\hline & & & & $(0.03)$ \\
\hline \multirow[t]{2}{*}{ Working } & & & & 0.04 \\
\hline & & & & $(0.03)$ \\
\hline \multirow[t]{2}{*}{ Education level } & & & & $-0.02^{* * *}$ \\
\hline & & & & $(0.00)$ \\
\hline \multirow[t]{2}{*}{ Income level } & & & & -0.01 \\
\hline & & & & $(0.02)$ \\
\hline$N$ & 1611 & 1558 & 1620 & 1479 \\
\hline adj. $R^{2}$ & 0.04 & 0.08 & -0.00 & 0.12 \\
\hline
\end{tabular}

Heteroscedasticity-consistent standard errors in parentheses

$\dagger$ significant at $p<.10 ;{ }^{*} p<.05 ;{ }^{* *} p<.01 ;{ }^{* * *} p<.001$

In Model 4 we include all three explanatory factors to see how much that alters the bivariate patterns. The size of both the traditionalism and authoritarianism coefficients are somewhat reduced, which is not surprising given that the correlation between them is 0.4 , but both of the scores remain statistically significant. ${ }^{15}$ In Model 4 we also include other relevant control variables: an indicator for age and sex of the respondents, whether they live in an urban area, whether they are married or working, their education level (measured with their number of years of education) and their self-reported income level. With the exception 
of being a woman - which is positively associated with expressing a preference for men in politics - and education level — which is negatively associated with it — none of these control variables come out as significant predictors.

Table 4: OLS regression models of the association between conservative values preference for a boy child

\begin{tabular}{|c|c|c|c|c|}
\hline & Model 1 & Model 2 & Model 3 & Model 4 \\
\hline \multirow[t]{2}{*}{ Intercept } & $-0.20^{* *}$ & $0.33^{* * *}$ & $0.56^{* * *}$ & 0.15 \\
\hline & $(0.07)$ & $(0.03)$ & $(0.02)$ & $(0.12)$ \\
\hline \multirow[t]{2}{*}{ Traditionalism score } & $0.07^{* * *}$ & & & $0.05^{* * *}$ \\
\hline & $(0.01)$ & & & $(0.01)$ \\
\hline \multirow[t]{2}{*}{ Authoritarianism score } & & $0.04^{* * *}$ & & $0.02^{* * *}$ \\
\hline & & $(0.01)$ & & $(0.01)$ \\
\hline \multirow[t]{2}{*}{ Religious practice } & & & 0.01 & -0.00 \\
\hline & & & $(0.01)$ & $(0.02)$ \\
\hline \multirow[t]{2}{*}{ Age } & & & & $-0.00^{*}$ \\
\hline & & & & $(0.00)$ \\
\hline \multirow[t]{2}{*}{ Urban locality } & & & & 0.03 \\
\hline & & & & $(0.03)$ \\
\hline \multirow[t]{2}{*}{ Woman } & & & & $-0.13^{* * *}$ \\
\hline & & & & $(0.03)$ \\
\hline \multirow[t]{2}{*}{ Married } & & & & 0.03 \\
\hline & & & & $(0.03)$ \\
\hline \multirow[t]{2}{*}{ Working } & & & & 0.01 \\
\hline & & & & $(0.03)$ \\
\hline \multirow[t]{2}{*}{ Education level } & & & & $-0.01^{* * *}$ \\
\hline & & & & $(0.00)$ \\
\hline \multirow[t]{2}{*}{ Income level } & & & & -0.02 \\
\hline & & & & $(0.02)$ \\
\hline$N$ & 1611 & 1558 & 1620 & 1479 \\
\hline adj. $R^{2}$ & 0.07 & 0.04 & -0.00 & 0.09 \\
\hline
\end{tabular}

Heteroscedasticity-consistent standard errors in parentheses

${ }^{\dagger}$ significant at $p<.10 ;{ }^{*} p<.05 ;{ }^{* *} p<.01 ;{ }^{* * *} p<.001$

In Table 4 we show the same models, but with preference for a boy child as the outcome variable. Here too, both the traditionalism and authoritarianism scores are robust to controlling for other factors and the intensity of religious practice is not significant. Here, being a woman is negatively associated with a boy preference, and so is age and education level. 
In summary, results from two national surveys conducted in the 2010s show that traditional and authoritarian values are common among Burmese voters, as are conservative gender attitudes. Despite superficial support for the idea of democracy, Burmese public opinion is more traditional and authoritarian than public opinion in other countries in Southeast Asia (Welsh et al. 2016), and provides a resource that anti-democratic forces can draw on to impede movement toward a more liberal regime, including advances in women's rights.

\section{Trajectories of women's rights under competitive elec- tions}

The previous section showed us that political attitudes in general, and attitudes towards gender equality in particular, are broadly conservative in Myanmar. How are these attitudes reflected in the evolution of women's rights? In this section we draw on secondary literature, as well as interviews and observations gained through fieldwork in 2016, to identify two parallel trends in the development of women's rights: one driven by feminist movements pushing for change and another driven by nationalist groups using women's issues as a mechanism to mobilize support from a conservative population.

The civilian government that assumed power in $2011^{16}$ made some moves to comply with its international obligations on women's rights and to collaborate with civil society to promote gender equality, including drafting a National Strategic Plan for Women's Advancement, launched in 2013. In 2012, the government enacted a new social security law, which expanded maternity benefits and extended them to men by creating paid paternity leave of up to 15 days and offering paternity grants. The 2012 minimum wage law requires employers to treat men and women workers the same, and the employment contract form required by the Ministry of Labor since 2012 also prohibits discrimination. 
Pushed by feminist groups, the civilian government took steps to address Myanmar's antiquated laws on sexual and gender violence. There is no domestic violence legislation and the main legal text relating to violence against women is the 1860 Penal Code. Under the Code, rape is punished, but marital rape is exempted from criminal penalties unless the "woman" is under 13 (Network 2013). The government has sponsored public awareness campaigns, supported research on violence and services offered by NGOs, and began to draft an anti-violence law in collaboration with civic groups (Faxon et al. 2015; Government of Myanmar 2015). To solicit input for the gender violence bill in 2013 and 2014, the Gender Equality Network (GEN), a coalition of feminist social movements, conducted over fifty workshops with women around the country and additional workshops with politicians and civil servants from dozens of administrative units (Faxon et al. 2015; Gender Equality Network 2015a). Yet by 2019, the state had not adopted a new law to combat gender and sexual violence. Key provisions in the proposal-such as measures to hold soldiers accountable for rapes committed in war zones - have encountered opposition. ${ }^{17}$

Besides lobbying and organizing, feminist groups have worked at the grassroots to change views among women. For example, they have engaged in consciousness-raising, as U.S. second wave feminists did in the 1970s, by creating groups where women speak together about their experiences, something few had previously done. As one of our activist interviewees reported, women "don't do a lot of experience sharing [...] even if they were raped they don't talk about it. They don't talk about sleeping with their partners either. They're not in a place where they closely and honestly share. So in our women's groups we try to get them to talk about sex-related issues and like that they started identifying violence and stuff on their own. After a 3-hour session, they would tell me "Ahhhh [name withheld] I feel so empowered!' So after 6 hours or 9 hours of discussion, 2 to 3 discussions, they'll start identify discriminating and violent behavior from their husbands and boyfriends. Those are things 
they never talk about. So we create these spaces with these ideas behind it." 18 Such efforts appear to be changing attitudes but are still small-scale in nature.

There are few other pressures for liberalization on women's rights besides urban feminist groups and the international human rights community. For example, there are few women in positions of power in the central government, as well as in the minority parties and insurgent groups in border areas (Minoletti 2016, 2019), a continuation of a long historical trend of low political presence. ${ }^{19}$ Aung San Suu Kyi is a woman, but Burmese tend to see her as an "exceptional" woman and not a sign of progress toward gender equality. In fact, Aung San Suu Kyi has condoned traditional gender roles and has not encouraged other women to aspire to leadership (Harriden 2012, p.235). As in other Southeast and East Asian countries, the presence of women in leadership bears little relation to norms and beliefs related to gender among the masses (Liu 2018).

Unlike insurgencies in other parts of the world, groups fighting the Myanmar military regime have tended to lack a discourse of women's liberation (Hedström 2016, p. 69). Further, as Hedstrom and Olivius show in their paper in this special issue, a gendered division of labor pervades informal, subsistence, and household economies in the border zones and in areas dominated by ethnic minorities. Most women lack access to land, engage in underpaid and precarious work, and perform a "second shift" caring for their family members and households, without public services or support.

The government has used the widepread perception that Burmese women are legally and historically equal - a perception that scholars criticize as a myth (Crouch 2016; Ikeya 2005) - to undermine feminist criticism of gender discrimination (Gender Equality Network 2015b). Elite conservative women voice the idea that since women are equal in Myanmar, a feminist movement is not necessary, a position which further limits the space for discussion of women's actual situation (Gender Equality Network 2015b; Than 2013). 
Progress toward the liberalization of women's rights has also been thwarted by the growing influence of Buddhist nationalist groups. Buddhist nationalist movements - such as the 969 movement and the Organization for the Protection of Race and Religion, known as Ma-Ba-Tha-gained prominence in the 2010s. These groups follow in an historical tradition of Buddhist mobilization aimed at defending a national identity against foreign threats, whether British colonialists, Indian workers, or Muslim minorities (Than 2015; Walton and Hayward 2014). Though their goal is to promote nationalism and not religious doctrine per se, Buddhist nationalists draw plentifully upon Theravada Buddhist teachings, which have historically framed the health of religion and the strength of the polity as interdependent, and been used to justify the use of violence against threats to the religious community (Than 2015; Walton and Hayward 2014). Growing access to the internet and the spread of Facebook provided crucial infrastructure for nationalist mobilization, much of it manifest in attacks on Muslim minorities. ${ }^{20}$

Nationalist and fundamentalist groups pushed for adoption of legislation intended to defend the Burmese Buddhist nation and marginalize outsiders, mainly Muslims but also other minorities. In 2015, on the eve of the country's first inclusive and participatory elections in decades, parliament approved four laws intended to "protect race and religion." The legislation achieves its goals via the regulation of marriage and reproduction. The package includes a "population control law" authorizing the government to take action-such as imposing birth spacing - to curb birth rates in certain regions; a Buddhist women's special marriage law allegedly intending to protect the rights of women who marry non-Buddhist men, but which also denies both women and men the freedom to marry by permitting multiple actors to object to the marriage and giving state officials final say in whether a marriage is legitimate; a monogamy law to prevent polygamous marriages, seemingly aimed at Muslims, though polygamy was also historically practiced among Burmese Buddhists 
(Crouch 2016); and a religious conversion law setting up a bureaucratic process to approve conversions to other religions (Barrow 2015; White 2015).

Though opposed by many civil society groups and the international community for violating women's rights and religious freedom, the laws enjoy broad popular support according to our fieldwork and a survey conducted by David and Holliday (2018). ${ }^{21}$ Participants in a qualitative research study conducted by the Gender Equality Network similarly emphasized the importance of preserving "race, ethnicity, religion, and culture." Women who marry outside of their religious group jeopardize these goals, and are sharply criticized (Gender Equality Network 2015b). As this suggests, women of the majority Burmese group have been enticed to support a restriction of liberal freedoms for the purpose of defending their communal identity.

What few in the international community, as well as non-lawyers in Myanmar, realize is that laws meant to "protect" Buddhist women in marriage have been on the books for many decades (Crouch 2015, 2016). As Crouch explains, a Buddhist Women's Special Marriage and Succession Act was adopted by parliament in 1939, and then revised and expanded in 1954 . The Act stipulates that Burmese Buddhist law will govern property, inheritance, and divorce in inter-religious marriages. Lawmakers and judges perceived that Burmese Buddhist law was more favorable to women than other forms of law recognized in the country's plural legal system, especially Muslim personal law (Crouch 2015, 2016). What is more, the country's Supreme Court issued directives in 1998 and 2012 that forbid Burmese Buddhist women from marrying foreign men unless the man was a Buddhist (Crouch 2015, , p.4). These laws and directives were issued prior to the emergence of the 969 movement and Ma-Ba-Tha, and before the outbreak of violence in Rakhine state and the coordinated attacks on the Rohingya people.

Ironically, the primary group harmed by the monogamy law is not Muslims but polygamous and adulterous Buddhist men, who are now vulnerable to criminal penalties for 
polygamy and adultery as well as the loss of all rights to property at divorce (Crouch 2016). However, publicity surrounding the "race and religion" laws has fortified the anti-Muslim sentiment that motivated their adoption, and further strengthened the linkage between women's rights and nationalism. Our analysis of survey data implies that, if political leaders and civic groups continue to promote national identity through conservative gender policies, women's rights are unlikely to advance as long as nationalism remains popular.

\section{Concluding discussion}

More than a half century ago, in 1963, Almond and Verba (2015) published results of the first cross-national survey of attitudes and norms underlying successful democracy. They found that a particular cluster of beliefs - a "civic culture" - accompanies robust democratic institutions. Bearers of the civic culture support norms of participation and engagement, but also defer to elites enough to give the government space to act. Though Almond and Verba's contribution, and political culture studies more generally, have fallen out of fashion, the findings in this paper concur with other recent studies arguing that contemporary scholars should continue to explore how the public's beliefs and attitudes affect the functioning and consolidation of democratic institutions (cf. Chu et al. 2008; Welsh et al. 2016).

Examination of political culture is particularly important in light of the inherent indeterminacy of competitive elections (cf. Przeworski 1991). Public opinion offers a guide to the policies elections are likely to produce. In stable democratic contexts such as Europe and the United States, right-wing populist parties have taken advantage of electoral victories to promote illiberal agendas such as the restriction of minority rights, press freedom, academic freedom, immigration, and horizontal accountability, causes that enjoy growing public support (Levitsky and Ziblatt 2018; Mudde 2016). In contexts with weaker democratic institutions, there is even greater danger that election winners will perceive tendencies 
in public opinion as grounds further to restrict rights, including the rights of women and minority ethnic groups.

Our paper shows that unequal views toward women's rights and gender roles hold across age groups in Myanmar. Even more than in other Asian countries, Burmese are likely to prefer boy children, believe men are better leaders than women in politics and business, and hold that a university education is more important for a boy than for a girl. In addition, there is widespread support for traditional and authoritarian political values (Welsh et al. 2016), and this conservative political culture is highly correlated with endorsement of gender inequality.

Myanmar's freer politics in the 2010s has generated two competing trends on women's rights. Feminists and human rights activists leverage international norms and agreementssuch as CEDAW - to pressure for advances in women's rights, such as more legislation to prevent and punish violence against women. Nationalists, on the other hand, draw on conservative public opinion, as well as perceptions of history and religion, to advance an illiberal agenda that targets minorities in particular but also opposes women's rights. As long as public opinion on women and gender remains conservative, traditional, and authoritarian, there is likely to be support for nationalism and skepticism of moves toward gender equality. Conflict over gender in majority-Buddhist Myanmar thus resembles trends in other countries, where competitive politics increased public contestation over women's rights (cf. Htun 2003; Kang 2015).

Though our analysis of survey data offer grounds for pessimism about the prospects for gender-equal change in Myanmar, it is important to bear in mind that people's attitudes may change quickly. In the United States, views on same sex marriage evolved dramatically in just a 15 year period. In 2004, 31\% of the population supported same sex marriage and $60 \%$ opposed it. By 2019, 61\% supported it and 31\% opposed. ${ }^{22}$ In Mexico in 2003, 56\% 
of women believed that a woman living with a partner should obey him, but by 2011, this share had dropped to $23 \%$ (Htun and Jensenius 2019).

In both countries, social movements relied on liberal, constitutional protections to organize campaigns to change public opinion. Feminist movements and human rights groups in Myanmar depend on these same freedoms. Feminist efforts to promote changes in attitudes rely on institutions that protect their liberal rights to organize, express opinions, participate, and communicate in ways that challenge the status quo. The fact that large portions of the Burmese public do not support these liberal principles constitutes a major obstacle to gender equality. The struggle to advance women's rights in Burma is closely connected to the promotion of liberal democracy. 


\section{Notes}

${ }^{1}$ Even before these two surveys, the International Republican Institute (IRI) released a survey about public opinion on political and economic topics. We do not analyze this survey as it included few questions on women and gender.

${ }^{2}$ See the presentation "Survey of Burma Public Opinion", accessed at www.iri.org.

${ }^{3}$ Nay Pyi Taw was not included since the township authorities did not permit the survey (Foundation 2014, p. 116). The survey had a response rate of 89.6\% (Foundation 2014, p. 120).

${ }^{4}$ The control variables include respondents' age (numerical 18-70), whether or not they live in an urban area (dummy variable based on survey question A6), gender identity, marital and work status, education level (a 1-9 ordinal scale based on survey question D5), and the income level of their family (an ordinal scale 1-10 based on survey question D9). The models also include fixed effects.

${ }^{5}$ Interview, Yangon, June 2016.

${ }^{6}$ Notes written by [name withheld] on June 15, 2016.

${ }^{7}$ The belief that women should isolate themselves during their menstrual cycles is widespread and not unique to Buddhism. One Christian woman we interviewed in Yangon reported that she was forbidden from participating in parties and celebrations of her church group when she was menstruating (Interview, Yangon, June 2016).

${ }^{8}$ Field notes from observations by [name withheld], November 22, 2016).

${ }^{9}$ Interview in Yangon, June 2016.

${ }^{10}$ Their figure for Myanmar differs slightly from ours, most likely because they do not exclude people who did not answer the question.

${ }^{11}$ This set of statements also includes a question about preference for having a boy child, which we exclude since we are considering this question to be an indicator of gender attitudes. The technical report about the survey states that this question is the least correlated with the rest, and that the traditionalism scale has a higher Cronbachs $\alpha$ when it is excluded.

${ }^{12}$ We also coded the score in an alternative way, assigning respondents a 4 if they say they "strongly agree", a 3 if they say "somewhat agree", a 2 for "somewhat disagree", and 1 for "strongly disagree." Averaging over the 13 statements we get an average of 3.3 on this 1-4 scale.

${ }^{13}$ Here we exclude a statement about women in politics, which we consider separately, as well as the statement "People with little or no education should have as much say in politics as highly-educated people", because it is framed the opposite of the other questions. 
${ }^{14}$ The alternative coding of assigning a numerical value to different responses results in an average value of 2 (on a scale running from 1-4). The traditional and authoritarian value scales are correlated at $\rho=0.4$.

${ }^{15}$ The variance inflation index is only 1.2 , suggesting that it is not problematic to include both in the same model.

${ }^{16}$ The government won power in the 2010 elections, which were boycotted by the National League for Democracy (NLD), the country's largest party, and widely regarded as failing to adhere to international standards of electoral integrity.

${ }^{17}$ On opposition to the proposal, see, e.g., Mike Ives, "As Myanmar Democratizes, Womens Rights Lag Behind," The New York Times, May 16, 2017.

${ }^{18}$ Interview, Yangon, June 2016 (translated from the Burmese).

${ }^{19}$ During the 1970 s and 1980 s, women made up less than $3 \%$ of parliament, and around the same share won seats in the 1990 elections. Military rule in the 1990s and 2000s meant few women in power, as women historically made up only some $1 \%$ of military personnel (Harriden 2012).

${ }^{20}$ See, e.g., Megan Specia and Paul Mozur, "A War of Words Puts Facebook at the Center of Myanmars Rohingya Crisis," The New York Times, October 27, 2017; Hannah Beech and Saw Nang, "In Myanmar, a Facebook Blackout Brings More Anger Than a Genocide Charge," The New York Times, August 31, 2018; Paul Mozur, "A Genocide Incited on Facebook, With Posts From Myanmars Military," The New York Times, October 15, 2018.

${ }^{21}$ Their surveys conducted in 2014 found that $60 \%$ of respondents nationwide support such laws; surveys in Yangon and Mandalay in 2017 found support from 75\% of respondents (David and Holliday 2018, pp.122$123)$.

${ }^{22}$ See [URL] www.pewforum.org/fact-sheet/changing-attitudes-on-gay-marriage. 


\section{References}

Almond, G. A. and S. Verba (2015). The civic culture: Political attitudes and democracy in five nations. Princeton university press.

Araújo, C., A. Calasanti, and M. Htun (2018). Women, power, and policy in brazil. In L. Schwindt-Bayer (Ed.), Gender and Representation in Latin America, pp. 211-227. Oxford University Press.

Baldez, L. (2001). Coalition politics and the limits of state feminism in chile. Women $\mathscr{G}$ Politics 22(4), 1-28.

Barrow, A. (2015). Contested spaces during transition: regime change in myanmar and its implications for women. Cardozo JL $\&$ Gender 22, 75.

Chu, Y.-h., L. Diamond, A. J. Nathan, and D. C. Shin (2008). How East Asians View Democracy. Columbia University Press.

Corrêa, S. (2017, December). Gender ideology: tracking its origins and meanings in current gender politics. Engenderings. LSE Department of Gender Studies.

Creppell, I. (2010). Secularization: Religion and the roots of innovation in the political sphere. In I. Katznelson and G. Stedman Jones (Eds.), Religion and the Political Imagination, pp. 23-45. Cambridge University Press.

Crouch, M. (2015). Constructing religion by law in myanmar. The Review of Faith $\&$ International Affairs 13(4), 1-11.

Crouch, M. (2016). Promiscuity, polygyny, and the power of revenge: The past and future of burmese buddhist law in myanmar. Asian Journal of Law and Society 3(1), 85-104. 
David, R. and I. Holliday (2018). Liberalism and democracy in Myanmar. Oxford University Press.

Dreze, J. and A. Sen (2002). India: Development and participation. Oxford University Press, USA.

Faxon, H., R. Furlong, and M. Sabe Phyu (2015). Reinvigorating resilience: violence against women, land rights, and the women's peace movement in myanmar. Gender $\mathcal{G}$ Development 23(3), 463-479.

Fish, M. S. (2002). Islam and authoritarianism. World politics 55(1), 4-37.

Fish, M. S. (2011). Are Muslims distinctive? A look at the evidence. Oxford University Press.

Foundation, A. (2014). Myanmar 2014: Civic knowledge and values in a changing society. Report by The Asia Foundation, published in San Francisco, CA.

Gender Equality Network (2015a). Behind the silence: Violence against women and their resilience: Myanmar. Technical report, Yangon, Myanmar.

Gender Equality Network (2015b). Raising the curtain: Cultural norms, social practices, and gender equality in myanmar. Technical report, Yangon.

Glick, P. and S. T. Fiske (1996). The ambivalent sexism inventory: Differentiating hostile and benevolent sexism. Journal of personality and social psychology 70(3), 491.

Government of Myanmar (2015). The combined fourth and fifth periodic myanmar national reports on the implementation of the convention on the elimination of all forms of discrimination against women. Technical report. 
Grzymała-Busse, A. (2015). Nations under God: How churches use moral authority to influence policy. Princeton University Press.

Haas, L. (2011). Feminist policymaking in Chile. Pennsylvania State University Press.

Harriden, J. (2012). The authority of influence: Women and power in Burmese history. NiAS Press.

Hedström, J. (2016). We did not realize about the gender issues. so, we thought it was a good idea: Gender roles in burmese oppositional struggles. International Feminist Journal of Politics 18(1), 61-79.

Heinen, J. and S. Portet (2010). Reproductive rights in poland: when politicians fear the wrath of the church. Third World Quarterly 31(6), 1007-1021.

Hesketh, T. and Z. W. Xing (2006). Abnormal sex ratios in human populations: causes and consequences. Proceedings of the National Academy of Sciences 103(36), 13271-13275.

Htun, M. (2003). Sex and the state: abortion, divorce, and the family under Latin American dictatorships and democracies. Cambridge University Press.

Htun, M. and F. Jensenius (2019). Aspirational laws as weak institutions: Legislation to combat violence against women in Mexico. In D. M. Brinks, S. Levitsky, and V. Murillo (Eds.), Weak Institutions in Latin America.

Htun, M. and S. L. Weldon (2018). States and the Logics of Gender Justice: State Action on Women's Rights around the World. New York, NY: Cambridge University Press.

Ikeya, C. (2005). The 'traditional' high status of women in burma: A historical reconsideration. Journal of Burma Studies 10(1), 51-81. 
Inglehart, R. and P. Norris (2003). Rising tide: Gender equality and cultural change around the world. New York: Cambridge University Press.

Inglehart, R. and C. Welzel (2005). Modernization, cultural change, and democracy: The human development sequence. Cambridge University Press.

Kang, A. J. (2015). Bargaining for Women's Rights: Activism in an Aspiring Muslim Democracy. University of Minnesota Press.

Khaing, M. M. (1984). The world of Burmese women. Zed Books.

Levitsky, S. and D. Ziblatt (2018). How democracies die. Crown.

Liu, S.-J. S. (2018). Are female political leaders role models? lessons from asia. Political Research Quarterly 71(2), 255-269.

Minoletti, P. (2014). Women's Participation in the Subnational Governance of Myanmar. Asia Foundation.

Minoletti, P. (2016). Gender (in) equality in the governance of myanmar: Past, present, and potential strategies for change. Yangon: The Asia Foundation.

Minoletti, P. (2019). Myanmar: Women's political life. In The Palgrave Handbook of Women's Political Rights, pp. 657-672. Springer.

Mudde, C. (2016). Europe's populist surge: A long time in the making. Foreign Aff. 95, 25.

Nathan, A. J. (2003, December 8-9). Patterns of traditionalism in east asia. In Conference on" How East Asians View Democracy", Taipei.

Nathan, A. J. (2007). Political culture and diffuse regime support in asia. Asia Barometer Working Paper Series 43, 1-38. 
Network, G. E. (2013). Myanmar laws and cedaw: The case for anti-violence against women laws. Technical report, Yangon, Myanmar.

Norris, P. and R. Inglehart (2011). Sacred and secular: Religion and politics worldwide (2nd ed.). Cambridge University Press.

Oxfam, C. (2013). Women and leadership in myanmar. Technical report, Yangon.

Przeworski, A. (1991). Democracy and the market: Political and economic reforms in Eastern Europe and Latin America. Cambridge University Press.

Razavi, S. and A. Jenichen (2010). The unhappy marriage of religion and politics: Problems and pitfalls for gender equality. Third World Quarterly 31(6), 833-850.

Rosado-Nunes, M. J. F. (2015). A “ideologia de gênero" na discussão do pne. a intervenção da hierarquia católica. HORIZONTE-Revista de Estudos de Teologia e Ciências da Religião 13(39), 1237-1260.

Sen, A. (2001). The many faces of gender inequality. New Republic October 27, 25-29.

Shin, D. C. and H. J. Kim (2017). Liberal democracy as the end of history: Western theories versus eastern asian realities. Asian Journal of Comparative Politics 2(2), 133-153.

Than, T. (2013). Women in modern Burma. Routledge.

Than, T. (2015). Nationalism, religion, and violence: Old and new wunthanu movements in myanmar. The Review of Faith \& International Affairs 13(4), 12-24.

Walton, M. J. and S. Hayward (2014). Contesting Buddhist narratives: Democratization, nationalism, and communal violence in Myanmar. Honolulu, HI: East-West Center.

Walton, M. J., M. McKay, and D. K. Mar Mar Kyi (2015). Women and myanmar's "religious protection laws". The Review of Faith 8 International Affairs 13(4), 36-49. 
Welsh, B. and K.-P. Huang (2016). Myanmar's political aspirations \& perceptions: 2015 asian barometer survey report. Taipeh: Center for East Asia Democratic Studies.

Welsh, B., K.-P. Huang, and Y.-h. Chu (2016). Burma votes for change: Clashing attitudes toward democracy. Journal of Democracy 27(2), 132-140.

White, C. (2015). Protection for whom? violations of international law in myanmar's new 'race and religion protection'laws. Georgetown Institute for Women, Peace and Security.

Zakaria, F. (1997). The rise of illiberal democracy. Foreign Aff. 76, 22. 


\section{Online Appendix}

Figure A1: Age and traditional and authoritarian values

\section{Age and traditional values}

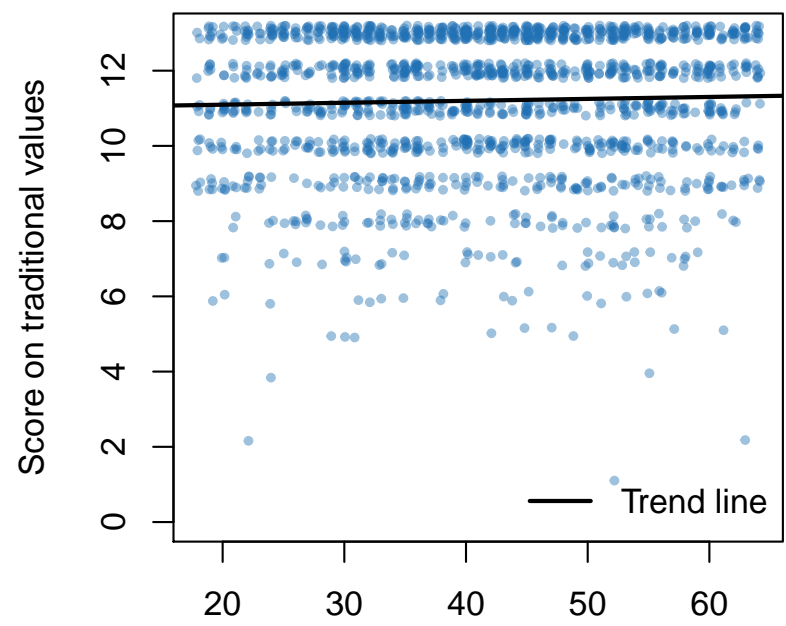

Age of respondent
Age and authoritarian values

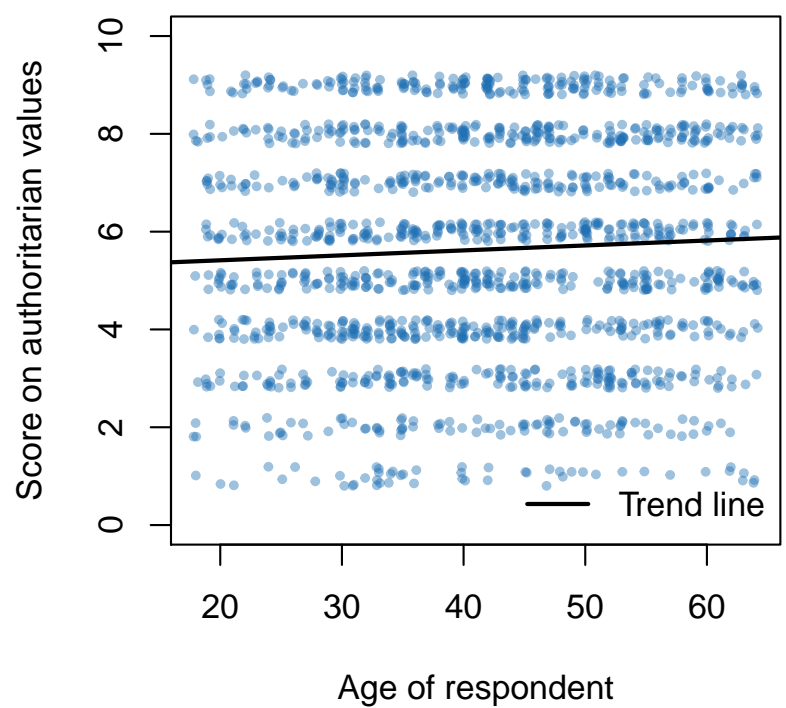

Note: The bivariate association between age of the respondents and their value on the traditionalism score, shown in the left panel, is statistically insignificant. The bivariate association between age and authoritarian values shown in the right panel is significant at the $5 \%$ level, but is no longer significant if we include other individual characteristics as control variables, such as gender, whether or not the person in working, and whether or not the person lives in a large city. 